\title{
ANALISIS JENIS PROFESI TERHADAP KEADAAN PENDIDIKAN DALAM KELUARGA PADA MASYARAKAT DUSUN TIBU BRENDE DESA GRENENG TIMUR
}

\author{
Khairil Anwar $^{1)}$, M. Isnaini ${ }^{2)}$, Linda Sekar Utami ${ }^{3)}$ \\ Program Studi Pendidikan Fisika, Universitas Muhammadiyah Mataram (Times New Roman, 9) \\ Kampus Induk, Jl.KH. Ahmad Dahlan N0.1 Pagesangan Mataram, Telp (0370) 630775 (Times New Roman, 9) \\ e-mail : hairil_physic@yahoo.com (Times New Roman, 9)
}

\begin{abstract}
Abstrak - Sumber Daya Manusia (SDM) merupakan asset yang paling penting dalam suatu tatanan kehidupan sosial, budaya dalam suatu lingkungan masyarakat maupun berbangsa dan bernegara, karena SDM memiliki peranan sebagai subyek pelaksana, kebijakan, dan operasional dan generasi penerus sebuah organisasi atau persyarikatan dalam suatu bangsa. Maka setiap pelaku dan penanggung jawab organisasi pendidikan haruslah memperhatikan dan memperdayakan sumber daya manusia dengan baik agar suatu kehidupan bermasyarakat berbangsa dan bernegara dapat berkembang. Dari unsur yang paling penting dan mendasar dalam pengembangan sumber daya manusia adalah unsur yang ada pada lingkungan keluarga maupun masyarakat. Dalam rangka pemberdayaan setiap unsur tersebut harus mampu saling mendukung dan memotivasi agar bersemangat dalam meningkatkan potensi dan keadaan masa depan masing-masing anggota keluarga atau masyarakat. Profesi masyarakat pedesaan pun kian beragam. Jenis-jenis profesi itu beragam mengikuti tingkat kemajuan berfikir masyarakatnya, namun profesi yang mendominasi masyarakat desa umumnya adalah petani namun tidak tertutup kemungkinan bahwa tingkat pendidikan anggota keluarganya bisa lebih tinggi seperti masyarakat perkotaan. Oleh karena itu orang tua harus memberikan bekal pendidikan yang baik. Sementara itu kebanyakan masyarakat pedesaan lebih menganggap bahwa tingkat pendidikan sampai Sekolah Menengah sudah cukup, Hal ini terlihat dari kurangnya masyarakat yang mencapai tingkat akademik hingga strata satu (S1). Salah satu penyebabnya karena tingkat profesi orang tua yang hidup di pedesaan masih mempunyai pola pikir yang konvesional. Sehingga hal inilah yang menjadi salah satu faktor mengapa penduduk suatu pedesaan masih sulit untuk berkembang. Tujuan dan target luaran atau hasil yang diharapkan dalam penelitian ini adalah: 1) Mengetahui tingkat profesi masyarakat, 2)Mengetahui taraf pendidikan dalam masyarakat. 3)mengetahui hubungan jenis profesi terhadap tingkat pendidikan dalam keluarga. Sehingga dengan penelitian ini dapat memberikan informasi kepada publik tentang keadaan suatu kelompok masyarakat di wilayah NTB. Hasil penelitian ini akan dijadikan sebagai dasar pemetaan kebijakan pada pelaksanaan program pengabdian masyarakat baik oleh lembaga akademik UM Mataram maupun lembaga pemerintah daerah dalam rangka peningkatan SDM pada suatu kelompok masyarakat desa, serta akan dipublikasikan dalam jurnal ilmiah, baik lokal maupun nasional terakreditasi. Konstribusi penelitian ini terhadap perkembangan ilmu pengetahuan adalah untuk menambah wawasan keilmuan bagi pelaku dan pemerhati Pendidikan sosial dalam rangka peningkatan mutu masyarakat desa.
\end{abstract}

Kata kunci : Jenis Profesi, Masyarakat Desa, Pendidikan.

\section{PENDAHULUAN}

Sumber Daya Manusia (SDM) merupakan asset yang paling penting dalam suatu tatanan kehidupan sosial, budaya dalam suatu lingkungan masyarakat maupun berbangsa dan bernegara, karena SDM memiliki peranan sebagai subyek pelaksana, kebijakan, dan operasional dan generasi penerus sebuah organisasi atau persyarikatan dalam suatu bangsa. Maka setiap pelaku dan penanggung jawab organisasi pendidikan haruslah memperhatikan dan memperdayakan sumber daya manusia dengan baik agar suatu kehidupan bermasyarakat berbangsa dan bernegara dapat berkembang. Dari unsur yang paling penting dan mendasar dalam pengembangan sumber daya manusia adalah unsur yang ada pada lingkungan keluarga maupun masyarakat. Dalam rangka pemberdayaan setiap unsur tersebut harus mampu saling mendukung dan memotivasi agar bersemangat dalam meningkatkan potensi dan keadaan masa depan masingmasing anggota keluarga atau masyarakat. Profesi masyarakat pedesaan pun kian beragam. Jenis-jenis profesi itu beragam mengikuti tingkat kemajuan berfikir masyarakatnya, namun profesi yang mendominasi masyarakat desa umumnya adalah petani namun tidak tertutup kemungkinan bahwa tingkat pendidikan anggota keluarganya bisa lebih tinggi seperti masyarakat perkotaan

Berdasarkan observasi non-sistematis yang dilakukan oleh peneliti pada beberapa lingkungan kehidupan bermasyarakat khususnya pedesaan masih terlihat sekitar 10\%-20\% dari jumlah penduduk suatu desa yang keadaan pendidikan anggota keluarganya terlihat baik. Hal ini terlihat dari kurangnya masyarakat yang mencapai tingkat akademik hingga strata satu (S1), sedangkan kebanyakan masyarakat pedesaan lebih menganggap bahwa tingkat pendidikan sampai Sekolah Menegah sudah cukup. Hal ini disebabkan salah satunya karena tingkat profesi orang tua yang hidup di pedesaan masih mempunyai pola pikir yang konvesional. Tingkat pendidikan penduduk pedesaan masih tergolong pendidikan menengah. Rata-rata penduduk pedesaan masih dalam taraf SMA. Hanya sedikit yang 
melanjutkan sampai ke jenjang perguruan tinggi. Menurut sumber informasi, mungkin hanya sekitar $20 \%$ yang melanjutkan ke tingkat perguruan tinggi. Mungkin hal inilah yang menjadi faktor mengapa penduduk suatu pedesaan masih sulit untuk berkembang. Untuk mewujudkan tujuan di atas sangat diperlukan peran keluarga sebagai pendukung sekaligus sebagai pendidik. Pimpinan dalam keluarga memiliki peran yang sangat penting dalam menentukan kuantitas dan kwalitas keadaan pendidikan dalam suatu keluarga. Oleh sebab itu, Keluarga harus memikirkan dan membuat perencanaan secara seksama dalam meningkatkan kesempatan belajar bagi anggota keluarganya. Pimpinan keluarga dituntut dan memotivasi agar mampu mengelola tingkat atau keadaan pendidikan dalam lingkungan keluarga sehingga dapat tercapainya tujuan pendidikan secara nasional yang diharapkan. Dalam rangka peningkatan kualitas pendidikan dalam lingkungan keluarga dibutuhkan peran serta orang tua sebagai pihak pertama untuk mengawasi dan mendukung proses pendidikan semua anggota keluarga.

\section{LANDASAN TEORI}

\subsection{Konsep Masyarakat}

Masyarakat merupakan kesatuan dari orang-orang yang hidup di daerah tertentu dan bekerjasama dalam kelompok-kelompok berdasarkan kebudayaan yang sama untuk mencapai kepentingan yang sama. Masyarakat memiliki ciri-ciri mempunyai wilayah, merupakan satu kesatuan penduduk, terdiri atas kelompok-kelompok fungsional yang heterogen, mengemban fungsi umum dan memiliki kebudayaan yang sama.

Dalam masyarakat terdapat dua macam, yaitu masyarakat desa dan mayarakat kota. Masyarakat kota biasanya hidup dalam kota-kota besar, dan sebaliknya masyarakat desa adalah masyarakat yang hidup di pedesaan. Desa merupakan satuan terkecil dari pemerintahan negara kita sejak zaman kerajaan hingga penjajahan dan kemerdekaan. Desa sendiri berasal dari bahasa india "Swadesa" yang berarti tempat tinggal negeri asal atau tanah leluhur yang merujuk pada suatu kesatuan hidup, dengan satu kesatuan norma serta memiliki batas yang jelas. Roucok dan Waren (dalam Yuliati, 2003:24) mendefinisikan desa sebagai bentuk yang diteruskan antar kedudukan dengan lembaga-lembaga di suatu wilayah dimana mereka tinggal, yaitu ladang-ladang dan di kampung yang biasanya menjadi pusat aktivitas nya.

Desa sebagai ruang masyarakat tradisional memiliki kecirian fisik yang di tandai oleh pemukiman yang tidak padat, sarana transportasi yang langka, penggunaan tanah persawahan. Kecirian lain berupa unsur-unsur sosial pembentuk desa yaitu penduduk dan tata kehidupan. Ikatan tali kekeluargaan di desa sangat erat dimana gemeinshaft menjadi dominan.

\subsection{Ciri-ciri masyarakat desa}

Adapun yang menjadi karakteristik masyarakat desa, adalah sebagai berikut.

1. Masyarakatnya erat sekali hubungannya dengan alam. Masyarakat desa pada umumnya sangat bergantung kepada alam. Tanah di pedesaan yang umumnya masih subur banyak dimanfaatkan oleh masyarakat untuk kelangsungan hidup mereka. Misalnya membuka lahan untuk pertanian padi, perkebunan, peternakan, dll.

2. Penduduk di desa merupakan unit sosial dan unit kerja. Penduduk desa merupakan suatu sistem yang terdiri dari beberapa kekerabatan yang menempati suatu wilayah sosial tertentu. Penduduk desa biasanya bila bekerja selalu bersama-sama atau berkelompok dengan penduduk lain membentuk satu unit kerja, misalnya dalam kegiatan panen maka secara otomatis penduduk akan berkelompok untuk mengerjakan pekerjaan tersebut.

3. Masyarakat desa mewujudkan paguyuban/gemainschaft. Paguyuban adalah bentuk kehidupan bersama dimana anggota-anggotanya diikat oleh hubungan batin yang murni dan bersifat alamiah serta bersifat kekal. Dasar hubungan ini adalah rasa cinta rasa kesatuan batin yang memang telah dikodratkan. Kehidupan tersebut dinamakan juga bersifat nyata dan organis.

Sedangkan unsur-unsur yang terkandung dalam sistem pedesaa adalah sebagai berikut.

1. Daerah, dalam arti tanah-tanah yang produktif dan yang tidak, beserta penggunaanya, termasuk juga unsur lokasi, luas dan batas yang merupakan lingkungan geografi setempat. Daerah ini berfungsi untuk menyediakan kemungkinan hidup, karena suatu masyarakat tidak bisa hidup tanpa ada daerah yang dapat dihuni olehnya.

2. Penduduk, adalah hal yang meliputi jumlah, pertambahan, kepadatan, persebaran dan mata pencaharian penduduk desa setempat. Penduduk bisa mempertahankan hidupnya setelah menempati daerah tadi. Penduduk juga bisa disebut sebagai orang-orang yang menempati suatu daerah.

3. Tata kehidupan, dalam hal ini pola tata pergaulan dan ikatan-ikatan pergaulan warga desa. Jadi, menyangkut seluk-beluk kehidupan masyarakat desa (rural society). Tata kehidupan, dalam artian yang baik memberikan jaminan akan ketenteraman dan keserasian hidup bersama di desa.

Para ahli seperti Mac.Iver, J.L.Gillin dan J.P. Gillin sepakat bahwa adanya saling bergaul dan interaksi karena mempunya nilai-nilai, norma-norma, cara-cara dan prosedur yang merupakan kebutuhan bersama sehingga masyarakat merupakan kesatuan hidup manusia yang berinteraksi menurut suatu sistem adat istiadat, yang bersifat kontinue dan terikat oleh suatu rasa identitas bersama.

\subsection{Kebijakan Pembangunan Masyarakat Desa}

Dalam Mudiono (2011) Pembangunan desa akan semakin menantang di masa depan dengan kondisi perekonomian daerah yang semakin terbuka dan kehidupan berpolitik yang lebih demokratis. Akan tetapi desa sampai kini, masih belum beranjak dari profil lama, yakni terbelakang dan miskin. Meskipun banyak pihak mengakui bahwa desa mempunyai peranan yang besar bagi kota, namun tetap saja desa masih dipandang rendah dalam hal ekonomi, pendidikan, ataupun yang lainnya. Oleh karena itu, sudah sewajarnya bila pembangunan pedesaan harus 
menjadi prioritas utama dalam segenap rencana strategi dan kebijakan pembangunan. Jika tidak, maka jurang pemisah antara kota dan desa akan semakin tinggi terutama dalam hal perekonomian, dan pendidikan. Adapun sasaran pokok pembangunan pedesaan adalah terciptanya kondisi ekonomi rakyat di pedesaan yang kukuh, dan mampu tumbuh secara mandiri dan berkelanjutan. Sasaran pembangunan pedesaan tersebut diupayakan secara bertahap dengan langkah: pertama, peningkatan kualitas tenaga kerja di pedesaan; kedua, peningkatan kemampuan aparatur pemerintah desa; ketiga, penguatan lembaga pemerintah dan lembaga masyarakat desa; keempat, pengembangan kemampuan sosial ekonomi masyarakat desa; kelima, pengembangan sarana dan prasarana pedesaan; dan keenam, pemantapan keterpaduan pembangunan desa berwawasan lingkungan. Pembangunan Masyarakat Desa pada dasarnya adalah bertujuan untuk mencapai suatu keadaan pertumbuhan dan peningkatan untuk jangka panjang dan sifat peningkatan akan lebih bersifat kualitatif terhadap pola hidup warga masyarakat, yaitu pola yang dapat mempengaruhi perkembangan aspek mental (jiwa), fisik (raga), intelegensia (kecerdasan) dan kesadaran bermasyarakat dan bernegara. Akan tetapi pencapaian objektif dan target pembangunan desa pada dasarnya banyak ditentukan oleh mekanisme dan struktur yang dipakai sebagai sistem pembangunan desa. Konsep perencanaan pengembangan desa mencakup 5 dimensi sebagai pilar utama yaitu menyangkut tata ruang desa, perekonomian desa, sosial budaya desa, mitigasi bencana, lingkungan hidup.

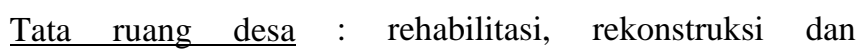
pengembangan desa. Selain itu, juga mampu menampung pertumbuhan ruang di masa datang secara fleksibel dan mampu menampung kebutuhan perbaikan struktur tata ruang desa melalui konsolidasi lahan (jika diperlukan). Konsep ini sesuai dengan muatan PP no 2 tahun 2005.

Perekonomian Desa : meningkatkan penghidupan masyarakat dan pembangunan sarana ekonomi berbasis potensi lokal, pengembangan usaha mikro, kelembagaan ekonomi dikaitkan dengan sumber daya manusia.

Sosial Budaya Desa : pembangunan pendidikan, sosial dan penguatan adat istiadat setempat dalam rangka pengembangan partisipasi masyarakat yang melibatkan segenap lapisan masyarakat, termasuk di dalamnya kelompok anak-anak pemuda dan wanita.

Mitigasi bencana: penataan ruang desa dengan fungsi khusus yaitu mitigasi bencana, berupa pembangunan daerah daerah yang rawan bencana dan tempat tempat yang digunakan untuk penampungan evakuasi warga ketika terjadi bencana.

Lingkungan hidup: penataan lingkungan yang menjaga keseimbangan holistik antara kawasan budidaya dengan kawasan lindung dalam upaya menjaga kelestarian penghidupan sebagian besar masyarakat. Penataan dilakukan juga terhadap pengelolaan di sektor pertanian, termasuk perkebunan, perikanan, kehutanan untuk meminimalisir ketidakseimbangan ekosistem.
Menurut Todaro (1998) pembangunan bukan hanya fenomena semata, namun pada akhirnya pembangunan tersebut harus melampaui sisi materi dan keuangan dari kehidupan manusia. Dengan demikian pembangunan idealnya dipahami sebagai suatu proses yang berdimensi jamak, yang melibatkan masalah pengorganisasian dan peninjauan kembali keseluruhan sistem ekonomi dan sosial. Berdimensi jamak dalam hal ini artinya membahas komponen-komponen ekonomi maupun non ekonomi. Todaro (1998) menambahkan bahwa pembangunan ekonomi telah digariskan kembali dengan dasar mengurangi atau menghapuskan kemiskinan, ketimpangan dan pengangguran dalam kontenks pertumbuhan ekonomi atau ekonomi negara yang sedang berkembang. Rostow (1971) juga menyatakan bahwa pengertian pembangunan tidak hanya pada lebih banyak output yang dihasilkan tetapi juga lebih banyak output daripada yang diproduksi sebelumnya. Dalam perkembangannya, pembangunan melalui tahapan-tahapan: masyarakat tradisional, pra kondisi lepas landas, lepas landas, gerakan menuju kematangan dan masa konsumsi besar-besaran. Kunci diantara tahapan ini adalah tahap lepas landas yang didorong oleh satu atau lebih sektor. Pesatnya pertumbuhan sektor utama ini telah menarik bersamanya bagian ekonomi yang kurang dinamis. Menurut Hanafiah (1892) pengertian pembangunan mengalami perubahan karena pengalaman pada tahun 1950-an sampai tahun 1960an menunjukkan bahwa pembangunan yang berorientasi pada kenaikan pendapatan nasional tidak bisa memecahkan masalah pembangunan. Hal ini terlihat dari taraf hidup sebagian besar masyarakat tidak mengalami perbaikan kendatipun target kenaikan pendapatan nasional per tahun meningkat. Dengan kata lain, ada tanda-tanda kesalahan besar dalam mengartikan istilah pembangunan secara sempit. Akhirnya disadari bahwa pengertian pembangunan itu sangat luas bukan hanya sekedar bagaimana menaikkan pendapatan nasional saja. Pembangunan ekonomi itu tidak bisa diartikan sebagai kegiatan-kegiatan yang dilakukan negara untuk mengembangkan kegiatan ekonomi dan taraf hidup masyarakatnya. Berbagai sudut pandang dapat digunakan untuk menelaah pembangunan pedesaan. Menurut Haeruman ( 1997 ), ada dua sisi pandang untuk menelaah pedesaan, yaitu:

1. Pembangunan pedesaan dipandang sebagai suatu proses alamiah yang bertumpu pada potensi yang dimiliki dan kemampuan masyarakat desa itu sendiri. Pendekatan ini meminimalkan campur tangan dari luar sehingga perubahan yang diharapkan berlangsung dalam rentang waktu yang panjang.

2) Sisi yang lain memandang bahwa pembangunan pedesaan sebagai suatu interaksi antar potensi yang dimiliki oleh masyarakt desa dan dorongan dari luar untuk mempercepat pemabangunan pedesaan.

Pembangunan desa adalah proses kegiatan pembangunan yang berlangsung didesa yang mencakup seluruh aspek kehidupan dan penghidupan masyarakat. Menurut peraturan Pemerintah Republik Indonesia no : 72 tahun 2005 tentang desa sebagaimana dimaksud pada ayat (2) bahwa perencanaan pembangunan desa disusun secara partisipatif 
oleh pemerintahan desa sesuai dengan kewenangannya dan menurut ayat (3) bahwa dalam menyusun perencanaan pembangunan desa wajib melibatkan lembaga kemasyarakatan desa.

Tujuan Perencanaan Pembangunan sebagai berikut:

1. Mengkoordinasikan antar pelaku pembangunan.

2. Menjamin sinkronisasi dan sinergi dengan pelaksanaan Pembangunan Daerah.

3. Menjamin keterkaitan dan konsistensi antara Perencanaan, Penganggaran, Pelaksanaan dan Pengawasan.

4. Mengoptimalkan Partisipasi Masyarakat

5. Menjamin tercapainya penggunaan Sumber Daya Desa secara efisien, efektif, berkeadilan dan berkelanjutan.

Kebijakan perencanaan pembangunan desa merupakan suatu pedoman-pedoman dan ketentuanketentuan yang dianut atau dipilih dalam perencanaan pelaksanakan (memanage) pembangunan di desa yang mencakup seluruh aspek kehidupan dan penghidupan masyarakat sehingga dapat mencapai kesejahteraan bagi masyarakat

- Produktivitas kegiatan ekonomi, seperti pertanian, peternakan mengalami peningkatan

- Proses produksi sedang mengalami perubahan cukup berat, melalui adopsi teknologi

- Komersialisasi sudah cukup tinggi, pasar digunakan untuk menjual hasil dan membeli input produksi

- Penggunaan tenaga kerja luar dan adanya pasar upah tenaga kerja mulai berkembang

- Memanfaatkan teknologi baru

- Produksi berorientasi pasar. Sebagian besar dijual untuk pasar sehingga jenis komoditi yang diproduksi selalu disesuaikan dengan keadaan harga pasar. Tujuan produksi adalah untuk memperoleh keuntungan sebesarbesarnya.

- Mulai menerapkan sistem Agribisnis Paradigma Pertanian berubah menjadi Agribisnis dan Agroindustri dan perdagangan berkembang.

- Masyarakat sangat menghargai pedidikan, bersedia melakukan human investment

- Masyarakat sudah mengadopsi kehidupan di kota. Perbedaannya kegiatan ekonominya adalah berbasis pedesaan seperti pertanian, industri desa.

Masalah-Masalah Dalam Pembangunan Masalah yang dikemukakan oleh Chayanov dan boeke, terutama didasarkan atas sistem sosial atau kebudayaan yang berakar dalam yang membuat Teori Ekonomi Modern seolah-olah tidak dapat diterapkan di desa-desa atau masyarakat seperti ini. Tetapi selain masalah yang berasal dari sistem sosial atau kebudayaan, sebenarnya banyak masalah lain yang menyebabkan timbulnya masalah pembangunan desa masalah-masalah tersebut terutama adalah:

1. Masalah pertumbuhan penduduk penduduk yang berat, sehingga pemilikan tanah semakin berkurang, terutama pada wilayah yang terbatas lahannya (Sumber Daya Alam)

2. Tingkat Pendidikan rendah yang menyebabkan adopsi teknologi rendah dan stagnansi produk juga masalah lain yang bisa timbul dengan serius seperti masalah kesehatan, rendahnya produktivitas kerja dan masalah kepemimpinan desa

Masalah ini perlu dimengerti keadaannya, agar kebijakan dan perencanaan pembangunan desa dapat dibuat dengan cukup lebih baik.

Pemerintahan Desa dalam menyelenggarakan kewenangannya dibidang pemerintahan, pembangunan dan kemasyarakatan untuk mewujudkan kemandirian serta kesejahteraan masyarakat belum dapat optimal karena terdapat berbagai permasalahan, seperti;

1. Terlalu cepatnya perubahan berbagai peraturan perundang-undangan sehingga menimbulkan kebingungan ditingkat pelaksana dan terkadang peraturan perundang-undangan yang dibutuhkan kurang lengkap dan memadai;

2. fasilitasi oleh Pemerintah dan Pemerintah Daerah masih sering terlambat;

3. terbatasnya tingkat kesejahteraan para penyelenggaran pemerintahan desa;

4. sebagian kualitas aparat pemerintahan desa masih terbatas dalam menggalang partisipasi masyarakat, menumbuhkan keswadayaan dan kemandirian dalam membangun, memanfaatkan, memelihara serta mengembangkan hasil-hasil pembangunan;

5. sangat terbatasnya sarana dan prasarana pemerintahan desa belum terdapat kepastian mengenai kewenangan dan sumber pendapatan

Prioritas yang akan dilaksanakan oleh Pemerintah

Daerah meliputi:

1. Pemantapan kerangka aturan:

Pemerintah, Peraturan Daerah, Peraturan Desa, Peraturan Kepala Desa dan Tata Tertib Badan Permusyawaratan Desa yang sesuai dengan prinsip keanekaragaman, demokratisasi, otonomi, partisipasi dan pemberdayaan masyarakat.

2. Penataan organisasi dan kewenangan:

Lingkup kegiatannya yaitu; penataan organisasi Pemerintah Desa, Badan Permusyawaratan Desa (BPD) dan Lembaga Kemasyarakatan Desa beserta kewenangan yang harus dimilikinya;

3. Pemantapan sumber pendapatan dan kekayaan desa: Lingkup kegiatannya yaitu; penataan manajemen perimbangan keuangan antara Kabupaten/Kota dengan Desa terutama mengenai alokasi dana desa, upaya peningkatan pendapatan asli desa, upaya penga-daan bantuan dari pemerintah dan pemerintah provinsi kepada desa, pembentukan badan usaha milik desa serta peningkatan dayaguna dan hasil guna aset yang dimiliki maupun yang dikelola oleh desa.

4. Penataan sistem informasi dan administrasi pemerintahan desa yang mudah, cepat, dan murah terutama yang berkaitan dengan kebutuhan dasar.

5. Pemantapan dan pengembangan kapasitas: Lingkup kegiatannya yaitu; meningkatkan kapasitas Kepala Desa, Perangkat Desa, anggota Badan Permusyawaratan Desa agar lebih mampu menyelenggarakan pelayanan kepada masyarakat secara demokratis, transparan dan akuntabel berdasarkan nilai-nilai sosial budaya setempat.

6. Pengadaan sarana dan prasarana: 
Lingkup kegiatannya yaitu; penyediaan sarana dan prasarana pemerintahan desa yang memadai dalam rangka melaksanakan tugas dan fungsinya sebagai pelayan masyarakat yang terdepan. Beberapa program-program pembangunan pedesaan yang pernah dilaksanakan, misalnya program bidang pangan, program Inpres Desa Tertinggal, merupakan salah satu upaya pemerintah dalam rangka mengembangkan pedesaan dalam mengejar ketertinggalannya dari perkotaan. Selain itu guna menyokong program pangan, pemerintah menyediakan bantuan Kredit Usaha Tani ( KUT ) bagi para petani dalam memberikan permodalan dalam pengelolaan lahannya. Akan tetapi program-program tersebut belum mampu meningkatkan kesejahteraan petani karena harga beras lokal masih relative lebih tinggi dibandingkan dengan harga beras impor. Sedangkan dana pengembalian KUT sampai saat ini banyak yang menunggak karena petani tidak mampu membayar cicilan tersebut. Adapun program IDT lebih cenderung pada pembangunan fisik saja sehingga penekanan terhadap pembangunan masyarakat umum kurang tersentuh. Padahal berbagai persoalan yang membutuhkan penanganan pembangunan masyarakat desa sesungguhnya sangat mendesak, seperti ketertinggalaan desa dari kota hampIr di segala bidang, tidak terakomodasinya keinginan dan kebutuhan masyarakat dalam program-program pemerintah, dan kualiatas pendidikan dan kesejahteraan masih rendah. Berdasarkan pengalaman tersebut sudah seharusnya pendekataan pembangunan pedesaan mulai diarahkan secara integral dengan mempertimbangkan kekhasan daerah baik dilihat dari sisi kondisi, potensi dan prospek dari masingmasing daerah. Namun di dalam penyusunan kebijakan pembangunan pedesaan secara umum dapat dilihat dalam tiga kelompok (Haeruman, 1997), yaitu :

1. Kebijakan secara tidak langsung diarahkan pada penciptaan kondisi yang menjamin kelangsungan setiap upaya pembangunan pedesaan yang mendukung kegiatan sosial ekonomi, seperti penyediaan sarana dan prasarana pendukung (pasar, pendidikan, kesehatan, jalan, dan lain sebagainya), penguatan kelembagaan, dan perlindungan terhadap aktivitas sosial ekonomi masyarakat melalui undang- undang.

2. Kebijakan yang langsung diarahkan pada peningkatan kegiatan ekonomi masyarakat pedesaan.

3. Kebijakan khusus menjangkau masyarakat melalui upaya khusus, seperti penjaminan hukum melalui perundang-undangan dan penjaminan terhadap keamanan dan kenyamanan masyarakat.

Di samping itu kebijakan pembangunan pedesaan harus dilaksanakan melalui pendekatan sektoral dan regional. Pendekatan sektoral dalam perencanaan selalu dimulai dengan pernyataan yang mengkut sektor apa yang perlu dikembangkan untuk mencapai tujuan pembangunan. Berbeda dengan pendekatan sektoral, pendekatan regional lebih menitik beratkan pada daerah mana yang perlu mendapat prioritas untuk dikembangkan, baru kemudian sektor apa yang sesuai untuk dikembangkan di masing-masing daerah. Di dalam kenyataan, pendekatan regional sering diambil tidak dalam kerangka totalitas, melainkan hanya untuk beberapa daerah tertentu, seperti daerah terbelakang, daerah perbatasan, atau daerah yang diharapkan mempunyai posisi trategis dalam arti ekonomi-politis. Oleh karena arah yang dituju adalah gabungan antara pendekatan sektoral dan regional, maka pembangunan daerah perlu selalu dikaitkan dimensi sektoral dengan dimensi spasial.

\subsection{Perbedaan Masyarakat Desa dan Kota}

Dalam masyarakat modern, sering dibedakan antara masyarakat pedesaan (rural community) dan masyarakat perkotaan (urban community). Menurut Soekanto (1994), per-bedaan tersebut sebenarnya tidak mempunyai hubungan dengan pengertian masyarakat sederhana, karena dalam masyarakat modern, betapa pun kecilnya suatu desa, pasti ada pengaruh-pengaruh dari kota. Perbedaan masyarakat pedesaan dan masyarakat perkotaan, pada hakekatnya bersifat gradual.

Kita dapat membedakan antara masya-rakat desa dan masyarakat kota yang masing-masing punya karakteristik tersendiri. Masing-masing punya sistem yang mandiri, dengan fungsi-fungsi sosial, struktur serta proses-proses sosial yang sangat berbeda, bahkan kadang-kadang dikatakan "berlawanan" pula. Perbedaan ciri antara kedua sistem tersebut dapat diungkapkan secara singkat menurut Poplin (1972) sebagai berikut:

\begin{tabular}{|l|l|}
\hline \multicolumn{1}{|c|}{ Masyarakat Pedesaan } & \multicolumn{1}{|c|}{ Masyarakat Kota } \\
\hline Perilaku homogen & Perilaku heterogen \\
\hline $\begin{array}{l}\text { Perilaku yang dilandasi } \\
\text { oleh konsep kekeluargaan } \\
\text { dan kebersamaan }\end{array}$ & $\begin{array}{l}\text { Perilaku yang dilandasi } \\
\text { oleh konsep pengandalan } \\
\text { diri dan kelembagaan }\end{array}$ \\
\hline $\begin{array}{l}\text { Perilaku yang berorientasi } \\
\text { pada tradisi dan status }\end{array}$ & $\begin{array}{l}\text { Perilaku yang berorientasi } \\
\text { pada rasionalitas dan } \\
\text { fungsi }\end{array}$ \\
\hline $\begin{array}{l}\text { Isolasi sosial, sehingga } \\
\text { statik }\end{array}$ & $\begin{array}{l}\text { Mobilitas sosial, sehingga } \\
\text { dinamik }\end{array}$ \\
\hline $\begin{array}{l}\text { Kesatuan dan keutuhan } \\
\text { kultural }\end{array}$ & $\begin{array}{l}\text { Kebauran dan diversifikasi } \\
\text { kultural }\end{array}$ \\
\hline $\begin{array}{l}\text { Banyak ritual dan nilai- } \\
\text { nilai sakral }\end{array}$ & $\begin{array}{l}\text { Birokrasi fungsional dan } \\
\text { nilai-nilai sekular }\end{array}$ \\
\hline Kolektivisme & Individualisme \\
\hline
\end{tabular}

Selain Tabel di atas, dalam menentukan suatu masyarakat sebagai kota atau desa dapat dilihat dari ciricirinya seperti berikut:

1. Jumlah kepadatan peduduk, kota memiliki penduduk yang lebih banyak daripada desa.

2. Lingkungan hidup di pedesaan terasa lebih dekat dengan alam bebas, lingkungan perkotaan sebagian besar dilapisi beton dan aspal.

3. Mata pencaharian masyarakat desa berada pada sektor ekonomi primer yaitu bidang agraris, sedangkan kota sektor ekonomi sekunder yaitu industri, dan ekonomi tersier yaitu bidang pelayanan jasa.

4. Corak kehidupan sosial di desa masih homogen, sebaliknya di kota sangat heterogen karena disana saling 
bertemu suku bangsa, agama, kelompok dan masingmasing memliki kepentingan berlainan.

5. Stratifikasi sosial di kota jauh lebih komplek dibanding desa. Misalnya mereka yang memiliki keahlian pekerjaan yang memerlukan banyak pemikiran memiliki kedudukan dan upah yang tinggi dibanding tenaga kasar. Hal ini berakibat perbedaan yang menyolok antara kaya dan miskin.

6. Mobilitas sosial di kota jauh lebih tinggi dibanding desa, baik secara vertikal yaitu perpindahan kedudukan yang lebih tinggi atau rendah, maupun perpindahan kedudukan yang setingkat atau horizontal.

7. Pola interaksi pada masyarakat pedesaan adalah motifmotif sosial, dalam interaksi sosial selalu diusahakan agar kesatuan sosial tidak terganggu, konflik atau pertentangan sosial sebisa mungkin dihindarkan. Sebaliknya pada masyarakat perkotaan dalam interaksi lebih dipengaruhi oleh ekonomi daripada motif sosial. Selain itu juga motif non sosial seperti politik, pendidikan.

8. Solidaritas sosial di desa lebih tinggi dibanding kota

9. Sedangkan dalam hirarki sistem administrasi nasional kedudukan kota lebih tinggi daripada desa, semakin tinggi kedudukan suatu kota dalam hirarki tersebut maka kompleksitasnya semakin meningkat/ makin banyak kegiatan disana.

Warga suatu masyarakat pedesaan mempunyai hubungan yang lebih erat dan lebih mendalam ketimbang hubungan mereka dengan warga masyarakat pedesaan lainnya. Sistem kehidupan biasanya berkelompok atas dasar sistem kekeluargaan (Soekanto, 1994). Selanjutnya Pudjiwati (1985), menjelaskan ciri-ciri relasi sosial yang ada di desa itu, adalah pertama-tama, hubungan kekerabatan. Sistem kekerabatan dan kelompok kekerabatan masih memegang peranan penting. Penduduk masyarakat pedesaan pada umumnya hidup dari pertanian, walaupun terlihat adanya tukang kayu, tukang genteng dan bata, tukang membuat gula, akan tetapi inti pekerjaan penduduk adalah pertanian. Pekerjaan-pekerjaan di samping pertanian, hanya merupakan pekerjaan sambilan saja ${ }^{1}$. Golongan orang-orang tua pada masyarakat pedesaan umumnya memegang peranan penting. Orang akan selalu meminta nasihat kepada mereka apabila ada kesulitan-kesulitan yang dihadapi. Nimpoeno (1992) menyatakan bahwa di daerah pedesaan kekuasaan-kekuasaan pada umumnya terpusat pada individu seorang kiyai, ajengan, lurah dan sebagainya. Ada beberapa ciri yang dapat dipergunakan sebagai petunjuk untuk membedakan antara desa dan kota. Dengan melihat perbedaan perbedaan yang ada mudah mudahan akan dapat mengurangi kesulitan dalam menentukan apakah suatu masyarakat dapat disebut sebagi masyarakat pedeasaan atau masyarakat perkotaan. Ciri ciri tersebut antara lain :

1) jumlah dan kepadatan penduduk

2) lingkungan hidup

3) mata pencaharian
4) corak kehidupan sosial

5) stratifiksi sosial

6) mobilitas sosial

7) pola interaksi sosial

8) solidaritas sosial

9) kedudukan dalam hierarki sistem administrasi nasional

\section{METODE PENELITIAN}

\subsection{Desain Penelitian}

Penelitian ini merupakan penelitian deskriptif yaitu penelitian yang dilakukan melalui nilai variabel mandiri, baik satu variabel atau lebih (independen) tanpa membuat perbandingan, atau menghubungkan antara variabel satu dengan variabel yang lain (Sugiyono, 2008). Penelitian ini dirancang dalam bentuk penelitian lapangan yang bersifat survei. Data diambil apa adanya di lapangan dengan menggunakan seperangkat instrumen.

\subsection{Waktu dan Tempat Penelitian}

Penelitian ini akan dilaksanakan bulan Februari 2014 pada awal pelaksanaan program KKN Universitas Muhammadiyah Mataram tahun akademik 2013/2014. Sedangkan tempat Penelitian dilaksanakan di dusun Tibu Brende desa Greneng Timur yang merupakan salah satu tempat atau lokasi pelaksanaan KKN Universitas Muhammadiyah Mataram tahun akademik 2013/2014.

\subsection{Subyek Penelitian}

Subjek dalam penelitian ini adalah kepala keluarga pada suatu masyarakat dusun Tibu Brende beserta dengan anggota dalam keluarga. Dalam penelitian ini yang menjadi variable bebas adalah jenis profesi kepala keluarga, sedangkan variabel terikatnya adalah keadaan pendidikan dalam anggota keluarga.

\subsection{Teknik Pengumpulan Data}

Data yang dikumpulkan berupa data tentang keadaan suatu masyarakat dalam setiap keluarga. Data diperoleh dengan cara memberikan dan mengisi form tertutup yang telah disediakan peneliti. Instrumen yang dipakai oleh peneliti adalah form yang memuat semua data-data yang berkaitan dengan keadaan profesi dan pendidikan keluarga. Instrumen pokok yang digunakan peneliti dalam mengumpulkan data adalah (1) mengenai identitas keluarga, (2) profesi dalam keluarga, dan (3) keadaan pendidikan anggota keluarga.

Dalam penilitian ini, ada beberapa teknik yang digunakan dalam pengumpulan data, yaitu: Dokumentasi, observasi, dan wawancara.

(1)Dokumentasi: Dokumentasi digunakan untuk memperoleh rekaman data visual atas keadaan geografis masyarakat.

(2)Observasi/pengamatan: Observasi digunakan untuk memperoleh data tentang respon, aktivitas, dan kompetensi subyek pada waktu penelitian dilaksanakan. 
(3)Wawancara: Wawancara dalam penelitian ini dimaksudkan untuk memperoleh data terkait respon subyek yang tidak tercantum dalam lembar instrument tertulis.

\subsection{Teknik Analisis Data}

Dalam penelitian ini, analisis data dilakukan dengan analisis deskriptif kualitatif. Menurut Iqbal Hasan (2004: 30), analisis kualitatif adalah analisis yang tidak menggunakan model matematika, model statistik, dan ekonometrik atau model-model tertentu lainnya. Dalam hal ini, sekadar membaca tabel-tabel, grafik-grafik, atau datadata yang tersedia dalam suatu dokumen, kemudian melakukan uraian dan penafsiran terhadap data-data hasil penelitian.

\section{HASIL DAN PEMBAHASAN}

\subsection{Hasil Penelitian}

Kegiatan penelitian ini dilaksanakan mulai minggu ke dua sampai miggu terakhir kegiatan KKN mahasiswa UM Mataram periode 2013-2014. Kegiatan pengumpulan data dilakukan setiap 3 hari turun ke lapangan dalam seminggu. Sedangkan masyarakat yang menjadi subyek penelitian adalah masyarakat dusun Tibu Berenda yang berjumlah 205 KK dimana merupakan bagian dari Desa Gereneng Timur Kecamatan Sakra Timur, Kabupaten Lombok Timur.

\subsubsection{Letak geografis desa greneng timur}

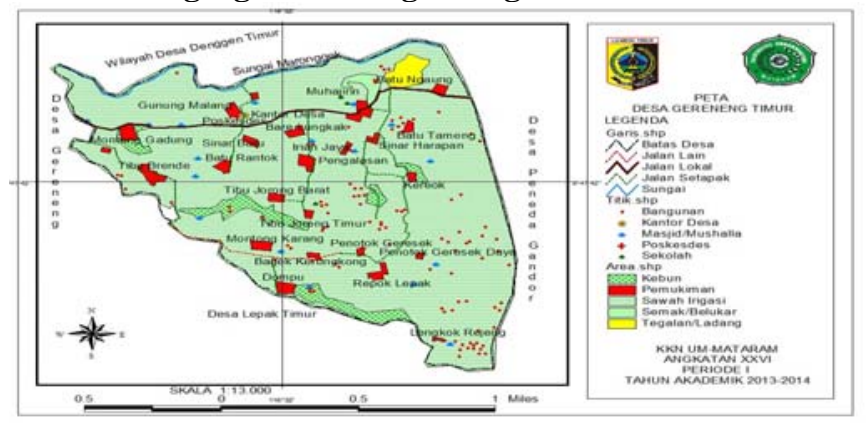

Desa Gereneng Timur yang merupakan desa pemekaran. Adapun batas-batas wilayah Desa Gereneng Timur adalah sebagai berikut :

1) Sebelah Utara

2) Sebelah Selatan

: Dusun Gunung Malang

3) Sebelah Timur

: Dusun Tibu Berende

4) Sebelah Barat

: Dusun Batu Tameng

: Dusun Motong Gadung

\subsubsection{Topografi Desa}

Desa Gereneng Timur terletak pada ketinggian 150$2000 \mathrm{~m}$ di atas permukaan laut dengan suhu yang sedang dan memiliki tanah yang cukup subur untuk dijadikan lahan pertanian dan perkebunan seperti tanaman padi, kedelai, sayur-sayuran dan tembakau serta sungai yang mengalirkan air cukup berlimpah untuk memenuhi kebutuhan tanaman akan air.

\subsubsection{Demografi Desa}

Desa Gereneng Timur terbagi atas 4 Dusun: Dusun Gunung Malang, Dusun Tibu Berende, Dusun Batu
Tameng, Dusun Motong Gadung. Desa Gereneng Timur memiliki luas 375,35 Ha yang dihuni oleh 4.417 jiwa, terdiri dari laki-laki 2.183 jiwa, perempuan 2.234 jiwa dengan kepala keluarga (KK) sejumlah $1.660 \mathrm{KK}$.

\subsubsection{Keadaan Penduduk}

Secara umum penduduk Desa Gereneng Timur dikatakan jarang berbanding dengan luas wilayah Desa Gereneng Timur. Jumlah penduduk 4.417 jiwa, KK yang terdiri dari 1.660 jiwa berdasarkan data registrasi penduduk pada bulan Maret Tahun 2014. Dengan rincian sebagai berikut:

Tabel 5.1 Data registrasi penduduk pada bulan Maret Tahun 2014

\begin{tabular}{|c|l|c|c|}
\hline No & Nama Dusun & Jumlah KK & Jumlah Jiwa \\
\hline 1 & $\begin{array}{l}\text { Gunung } \\
\text { Malang }\end{array}$ & 669 & 1649 \\
\hline $\mathbf{2}$ & Tibu Berende & $\mathbf{2 0 5}$ & $\mathbf{7 4 2}$ \\
\hline 3 & Motong Gadung & 268 & 800 \\
\hline 4 & Batu Tameng & 518 & 1226 \\
\hline \multicolumn{2}{r|}{ Jumlah } & $\mathbf{1 6 6 0}$ & $\mathbf{4 4 1 7}$ \\
\hline
\end{tabular}

(Sumber: laporan penduduk bulan Maret 2014).

Tabel 5.2 Keadaan Profesi Penduduk Tibu Brende

\begin{tabular}{|c|l|c|c|}
\hline No & Jenis Profesi & Jumlah & Prosentase \\
\hline 1 & Buruh Tani & 37 & 20,56 \\
\hline 2 & Petani/Tani & 112 & 62,22 \\
\hline 3 & Wiraswasta & 17 & 9,44 \\
\hline 4 & Guru & 10 & 5,56 \\
\hline 5 & PNS & 4 & 2,22 \\
\hline \multicolumn{2}{|c|}{ Jumlah } & $\mathbf{1 8 0}$ & $\mathbf{1 0 0}$ \\
\hline
\end{tabular}

Tabel 5.3 Keadaan Ekonomi Penduduk Tibu Brende

\begin{tabular}{|c|c|c|c|}
\hline No & $\begin{array}{c}\text { Tingkat } \\
\text { Pendapatan }\end{array}$ & Jumlah & Prosentase \\
\hline 1 & $<500.000$ & 116 & 64,44 \\
\hline 2 & $<1000.000$ & 39 & 22 \\
\hline 3 & $<1.500 .000$ & 18 & 10 \\
\hline 4 & $>1.500 .000$ & 7 & 3,89 \\
\hline \multicolumn{2}{|r|}{ Jumlah } & 180 & 100 \\
\hline
\end{tabular}

Tabel 5.4 Pandangan Pendidikan oleh masyarakat Tibu Brende

\begin{tabular}{|c|l|c|c|}
\hline No & \multicolumn{1}{|c|}{$\begin{array}{c}\text { Pandangan } \\
\text { Masyarakat }\end{array}$} & Jumlah & Prosentase \\
\hline 1 & Sangat Penting & 98 & 54,44 \\
\hline 2 & Penting & 77 & 42,78 \\
\hline 3 & $\begin{array}{l}\text { Tidak terlalu } \\
\text { penting }\end{array}$ & 5 & 2,73 \\
\hline \multicolumn{2}{|c|}{ Jumlah } & $\mathbf{8 3}$ & $\mathbf{1 0 0}$ \\
\hline
\end{tabular}

Tabel 5.5 Target maksimal Pendidikan anggota dalam keluarga

\begin{tabular}{|c|l|c|c|}
\hline No & \multicolumn{1}{|c|}{$\begin{array}{c}\text { Target } \\
\text { Pendidikan }\end{array}$} & Jumlah & Prosentase \\
\hline 1 & s/d SD & 0 & 0 \\
\hline 2 & s/d SMP & 14 & 7,78 \\
\hline 3 & s/d SMA & 123 & 68,33 \\
\hline 4 & s/d S1 & 43 & 23,89 \\
\hline 5 & s/d S2 & 0 & 0 \\
\hline
\end{tabular}




\begin{tabular}{|c|c|c|c|}
\hline \hline 6 & s/d S3 & 0 & 0 \\
\hline \multicolumn{2}{|c|}{ Jumlah } & $\mathbf{8 3}$ & $\mathbf{1 0 0}$ \\
\hline
\end{tabular}

Tabel 5.6 Sumber kehawatiran dalam mencapai target pendidikan keluarga

\begin{tabular}{|c|l|c|c|}
\hline No & $\begin{array}{c}\text { Bentuk } \\
\text { Kehawatiran }\end{array}$ & Jumlah & Prosentase \\
\hline 1 & Ekonomi & 145 & 80,56 \\
\hline 2 & Kemampuan Anak & 27 & 15 \\
\hline 3 & Budaya & 6 & 3,33 \\
\hline 4 & Dll. & 0 & 0 \\
\hline \multicolumn{2}{|c|}{ Jumlah } & $\mathbf{8 3}$ & $\mathbf{9 8 , 8 9}$ \\
\hline
\end{tabular}

Tabel 5.7 Tingkat prestasi anggota keluarga

\begin{tabular}{|c|l|c|c|}
\hline No & Tingkat Prestasi & Jumlah & Prosentase \\
\hline 1 & Peringkat Kelas & 23 & 12,78 \\
\hline 2 & Bidang Seni & 0 & 0 \\
\hline 3 & Bidang Olahraga & 0 & 0 \\
\hline 4 & dll. & 25 & 14 \\
\hline \multicolumn{2}{|c|}{ Jumlah } & $\mathbf{8 3}$ & $\mathbf{2 6 , 6 7}$ \\
\hline
\end{tabular}

\subsection{Pembahasan}

Secara umum penduduk Desa Gereneng Timur dikatakan jarang berbanding dengan luas wilayah Desa Gereneng Timur. Jumlah penduduk 4.417 jiwa, KK yang terdiri dari 1.660 jiwa berdasarkan data registrasi penduduk pada bulan Maret Tahun 2014. Keadaan masyarakat Desa Greneng Timur masih dikatakan cukup baik jika dilihat dari segi kesehatan, karena masyarakat setempat masih sadar akan pentingnya kesehatan mengingat pekerjaan sebagai petani yang mereka lakoni setiap hari harus membutuhkan tenaga fisik yang sehat demi kelangsungan hidup mereka, tetapi khususnya dibidang pendidikan masih dikatakan kurang dan keterbatasan dalam dunia informasi baik tentang pengetahuan, dan teknologi secara umum. Permasalahan tersebut timbul karena paradigma-paradigma masyarakat masih melekat yang mungkin diwarisi secara adat istidat atau nenek moyangnya dimana masyarakat khususnya anak anak yang beranjank dewasa menjalankan pernikahan diusia dini, sehingga pola pikir tentang melanjutkan pendidikan ke jenjang yang lebih tinggi masih minim. Namu dari aspek spiritualitas cukup bagus karena suasana religius yang masih kental di desa Gereneng Timur khususnya di dusun Tibu Brende karena belajar mengaji bagi anak-anak begitu antusias.

Secara garis besar masyarakat Dusun Tibu Brende mempunyai profesi sebagai petani dan buruh tani (Tabel 5.2) sebesar 62,22\% dan 20,56\% sedangkan sisanya merupakan wiraswasta dan Guru atau PNS. Sedangkan berdasarkan profesi tingkat pendapatan secara ekonomi masyarakat dusun Tibu Brende masih dikatakan rata-rata dalam angka kemiskinan, sebagaimana ditunjukkan dalam Tabel 5.3. Jumlah KK yang dikategorikan miskin adalah 116 jiwa karena berpenghasilan kurang dari Rp.500.000,/bulan atau sebesar 64,44\% dari jumlah KK.

Keadaan pendidikan masyarakat Dusun Tibu Brende masih kurang baik karena sarana dan prasarana penunjang pendidikan yang masih kurang terutama Tenaga pendidik, sehingga permasalahan dalam bidang pendidikan yaitu memerlukan bantuan tenaga pendidik. Hal ini pun terlebih lagi target maksimal pendidikan dalam anggota keluarga rata-rata hanya sampai tingak SMAyaitu sebesar 68,33\%, sedangkan yang menempuh study hingga sarjana S1 hanya sebesar 23,89\%, untuk program level pasca sarjana tidak ada satupun. Namun meskipun demikian, pola pikir masyarakat Dusun Tibu Brende sudah dikatakan dapat berpikir maju terhadap pendidikan, hal ini terlihat bahwa pandangan mayoritas masyarakat terhadap pendidikan keluarga sangat penting. Namun masalah yang paling besar yang menjadi kekhawatiran masyarakat untuk mencapai tingkat pendidikan yang tinggi yaitu hanya karena masalah Ekonomi yaitu sebesar 80\%, sehingga berdasakan data ini bantuan pendidikan yang menjangkau sangatah diperlukan oleh masyarakat desa.

Masalah Terkait bidang pendidikan angka buta aksara khususnya untuk Lansia banyak sekali sehigga dampaknya kesulitan dalam berkomunikasi karena faktor tidak bisa membaca dan berbahasa Indonesia. Sarana pendidikan di salah satu MI/MTs yang terdapat di desa Gereneng Timur Dusun Tibu Berenda cukup memprihatinkan karena kurang memadai baik bentuk bangunan itu sendiri dan kurangnya tenaga pendidik. Begitupun dengan kondisi spritual atau keagamaan kurangnya pemuda-pemudi untuk meramekan masjid-masjid maupun mushola-mushola untuk sholat berjamaah dan tidak adanya semangat kolektif dan kolegial masyarakat untuk melakukan perbaikan terhadap Masjid. Beberapa permasalahan antara lain:

a. Banyaknya anak putus sekolah serta rendahnya motivasi untuk sekolah

b. Kurangnya sarana dan prasarana pendukung disekolah, seperti: perpustakaan, buku-buku paket atau modul, dan alat-alat olah raga.

c. Kurangnya perhatian orang tua terhadap pendidikan anaknya.

Altrnatif pemecahan masalahnya adalah pemerintah diharapkan untuk memberikan program Buta Aksara untuk mengurangi Buta Aksara di Desa Gereneng Timur khususnya Dusun Tibu Brende agar program ini benar-benar dijalankan, sehingga benar-benar mendidik umat, khususnya ibu-ibu dan bapak-bapak karena merekalah yang akan mendidik generasi selanjutnya dengan ilmu pengetahuan yang mereka miliki. Sedangkan di bidang sosial budaya, nyongkolan memang adat yang sudah berakar dikalangan suku sasak, sehingga timbul perasaan sensitif jika suatu adat dibatasi, untuk itu warga harus diberi pemahaman dan kesadaran yang harus dilandasi dengan prinsip komunikasi yang baik, jangan sampai kegiatan nyongkolan yang mendatangkan orghen-orghen tidak menyebabkan mereka mabuk-mabukkan, sehingga orang tidak akan memandang miring terhadap adat yang bersih menjadi tercoreng oleh oknum-oknum tertentu. Serta kegiatan nyongkolan ini harus ada pengawasan dari polisi, karena dampaknya ketika turun dijalan, jalanan menjadi macet untuk itu perlu penertiban agar semuanya lancar. Begitupun dengan spiritual atau keagamaan perlu himbauan agar masyarakat tidak apatis dengan kegiatan gotong royong khusunya kepada masjid. Keadaan sosial budaya masyarakat Desa Gereneng Timur sangat bagus, karena budaya gotong royong yang masih kental sehingga memiliki nilai tambah pada masyarakat Desa Gereneng Timur khususnya Dusun Tibu Brende. 
Sedangkan kegiatan TPQ sangat bagus karena telah berjalan. Selain itu perlu dilakukan kegiatan-kegiatan sebagai berikut:

a. Pembinaan kegiatan pramuka bagi pelajar, genrasi muda dan krang taruna.

b. Program keaksaraan fungsional bagi masyarakat buta aksara.

c. Pembinaan dan peningkatan kegiatan keagamaan dan toleransi antar umat beragama.

d. Pembentukan dan pembinaan TPA.

e. Membantu meningkatkan kualitas proses belajar mengajar pada lembaga-lembaga pendidikan setempat.

\section{Penutup}

Berdasarkan hasil penelitian dapat disimpulkan bahwa jenis profesi kepala keluarga sangat mempengaruhi tingkat pendidikan anggota dalam keluarga pada masyarakat Dusun Tibu Brende. Oleh karena itu UM. Mataram (Universitas Muhammadiyah Mataram) harus selalu berperan aktif dalam ikut serta membangun masyarakat desa melalui pengabdian dan lain sebagainya baik itu yang dilaksanakan bersamaan dengan kegiatan KKN mahasiswa maupun Dosen dan civitas akademika dalam rangka usaha pemantauan dan peningkatan SDM di daerah-daerah yang masih membutuhkan perhatian lebih. Karena melalui kegiatan ini Universitas Muhammadiyah Mataram dapat memberikan sumbangsih yang nyata ikut serta mengembangkan dan memajukan kehidupan bermasyarakat, berbangsa dan bernegara.

\section{DAFTAR PUSTAKA}

Ahmadi, Abu. 2003. Ilmu Sosial Dasar. Jakarta: Rineke Cipta.

Aris Tanudirjo, Daud. 1993. Sejarah Perkembangan Budaya di Dunia dan di Indonesia. Yogyakarta:Widya Utama

Arikunto, Suharsimi. 2008. Prosedur Penelitian (Suatu Pendekatan Pratek). Jakarta: Rienika Cipta.

------------. 2011. Dasar-Dasar Evaluasi Pendidikan. Jakarta: Bumi Aksara.

Armstrong, M. 1994. Manajemen Sumber Daya Manusia. Jakarta: Media Kompetindo.

Dafidoft, Linda L. 1987. Introductions of Psychology. New Work: McGraw Hill Book Company.

Ermaya Suradinata. 1997. Pemimpin dan Kepemimpinan Pemerintahan. Jakarta: PT Gramedia Pustaka.

Gumgum Gumilar, 2001. Teori Perubahan Sosial. Unikom. Yogyakarta.

Handoko, T. Hani. 2001. Manajemen Personalia dan Sumber Daya Manusia. Yogyakarta: BPFE.

Hasibuan, Muhammad. 2003. Manajemen Sumber Daya Manusia. Jakarta: Bumi Aksara.

Kosim, H, E. 1996. Bandung: Sekolah Tinggi Bahasa Asing Yapari

Lane, Jan Erik. 1995. The Public Sectors, Concept, Model and Approaches. London: Sage Publications.
Marwanto, 12 November 2006. Jangan bunuh desa kami. Jakarta:Kompas.

Mudjiono. (2011). Kebijakan perencanaan kabupaten melalui pembangunan desa. Makalah.

Martoyo, Susilo. 2000. Manajemen Sumber Daya Manusia. Yogyakarta: BPFE.

Panggabean, Mutiara S. 2002. Manajemen Sumber Daya Manusia. Jakarta: Ghalia Indonesia.

Riduwan dan Sunarto. 2010. Pengantar Statistika. Bandung: Alfabeta.

Soekmono, R.tt. 1988. Pengantar Sejarah Kebudayaan Indonesia. Jakarta:Kanisius.

Suyanto, 2002. Merefleksikan Perubahan Sosial Masyarakat Indonesia. Kompas, 17 Desember 2002, hal. 5.

Stonner, James AF, R. Edward Freeman, Daniel R. Gilbert JR. 1996. Manajemen. Jilid II. Jakarta: Prenhalindo.

Sardiman. 2007. Interaksi dan Motivasi Belajar Mengajar. Jakarta: PT Raja Grafindo Persada.

Sugiyono. 2008. Metode Penelitian Administrasi. Bandung: Alfabeta.

Simamora, H. 2003. Manajemen Sumber Daya Manusia. Edisi Kedua. Yogyakarta: Bagian Penerbitan STIE YKPN.

Tim Manajemen. 2012. Buku Pedoman Universitas Muhammadiyah Mataram. Percetakan: Mataram.

Uno, Hamzah B. 2008. Teori Motivasi dan Pengukurannya. Gorontalo: Bumi Aksara.

Widoyoko, Eko Putro. 2012. Teknik Penyusunan Instrumen Penelitian. Yogyakarta: Pustaka Pelajar. 